\title{
The Prospects for Burglary Prevention in Australia
}

\author{
TIM PRENZLER ${ }^{\dagger}$ AND MICHAEL TOWNSLEY ${ }^{\ddagger}$
}

On the 5th of June 1997, the Australian Prime Minister John Howard launched the National Campaign Against Violence and Crime (NCAVC). The campaign involves $\$ 13$ million expended over three years on a range of projects aimed at reducing crime and crime-related problems. Specific components target problems such as domestic violence, fear of crime, and violence in public places. $\$ 230,000$ has been allocated for review of developmental programs for children, and policy development and piloting of an intervention program. $\$ 330,000$ has been set aside for a residential burglary project based on situational prevention principles such as target hardening and defensible space, focusing on preventing repeat victimisation, and including action such as property marking, upgrading of physical security and reducing the retail market for stolen property. This project has the largest funding allocation in the campaign, reflecting the statement that 'residential burglary is one of the most common crimes in Australia and is an issue of major concern to the Australian public' (NCAVC 1997). What are the prospects for reducing burglary in Australia and what is the prospective impact of the NCAVC projects?

This article reviews the extent, costs and causes of burglary; and reports on both successful and unsuccessful anti-burglary strategies. Burglary prevention is possible, but in Australia the prospects for major reductions are extremely poor. Current social trends are almost all criminogenic for this type of crime. Opportunities in the built environment are facilitated by increasing prosperity, increasing population densities and residential mobility, the continuing proliferation of consumer goods, and the consumption of services outside the home. Motives to take advantage of opportunities are fuelled by economic and cultural inequality and alienation, and the continuing demand for illegal drugs.

Substantial reductions in burglary in both residential and commercial settings can only be achieved by highly eclectic means. Strategies which have shown some success are wide ranging and include measures such as property identification schemes, sound security management strategies in commercial premises, and insurance company sponsored home security programs. The article also considers 'upstream' strategies such as liberal methadone programs, and other approaches with less direct empirical support, but with rich potential. Integrated theory is essential to link the complex causes of burglary, but a feminist perspective is particularly useful given the salience of young men in the profile of burglars and the conflicts in male socialisation which contribute to this disproportionate representation. A brief exploration of the gender dimension supports a focus on early

* The main text of this paper was presented at the Second National Outlook Symposium hosted by the Australian Institute of Criminology in Canberra, 3-4 March 1997. Thanks to Tom Pudney for permission to use NRMA graphs.

$\uparrow$ Senior Lecturer, School of Justice Administration, Griffith University, Brisbane

$\ddagger$ PhD Candidate, School of Justice Administration, Griffith University, Brisbane. 
childhood interventions and social equity programs for adolescents at risk of a range of selfvictimising behaviours and victimisation of others, including burglary. Burglary will continue to plague Australians until politicians and policy makers adopt a radical and diverse package of strategies, many of which will not be specifically targeted at preventing burglary.

\section{Extent and cost of burglary}

Most Western countries experienced significant increases in crime, including burglary, in the 1960s and 70s in association with rapid economic growth, the availability of easily stolen consumer products, and the movement of work and social life away from the home (Cohen and Felson 1979). In the United States - the international point of comparison for crime - burglary has been one of the most common 'street crimes', which increased rapidly during the 1960s up to the mid-1980s and has since stabilised (Shover 1991). In Australia, it is clear that the rate of increase in burglary has declined but there is contradictory data on current trends. One recent review of police reports and victim surveys identified a small level of increase in the 1990s (Grabosky 1995). Figures from the NRMA, a major insurer on the East Coast, showed stable rates in the 1990s (Figure 1), although the cost of burglary increased (Figure 2). Burglary claims in NSW alone cost the NRMA $\$ 37.3$ million in 1995/96 - a 12\% increase from the previous financial year (not counting inflation) and a 71\% increase over five years (NRMA 1996:4).

Figure 1 NRMA burglary claims, 1982-1996*

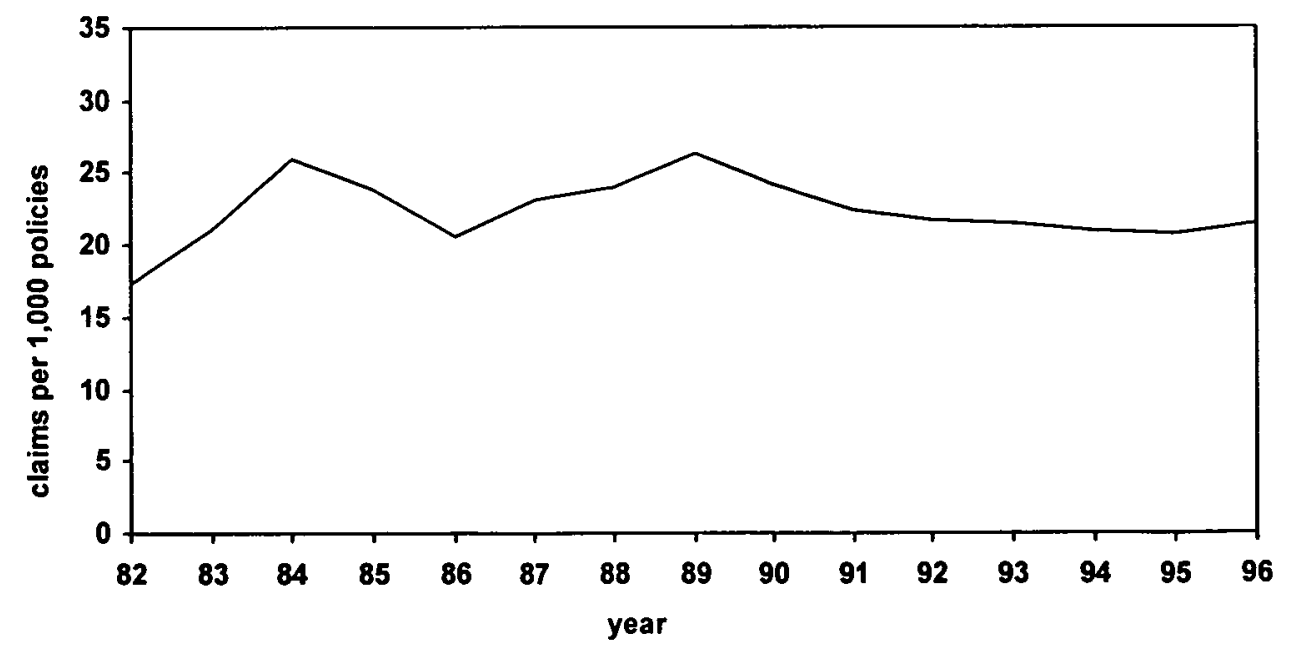

* Financial year ending 30 June. Used with permission: NRMA 1996:5. 
Figure 2 NRMA burglary costs, 1982-1996*

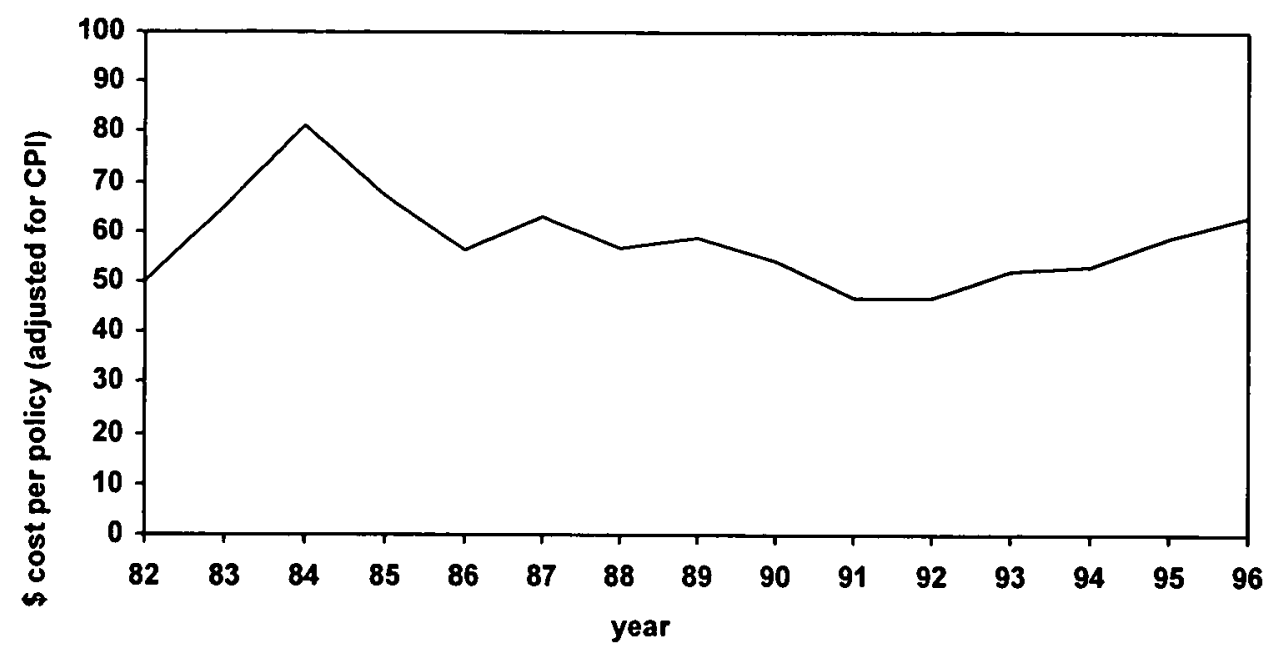

* Financial year ending 30 June. Used with permission: NRMA 1996:5.

The first international crime victim survey, conducted in 1989, gave Australia the highest rate of home burglary (4.4\% of respondents compared to the next highest rate of $3.8 \%$ in the US) (van Dijk et al 1991:23). The Australian component of the 1992 survey found that $4.2 \%$ of households had been burgled in the preceding year - a figure claimed by the authors to be a probable overestimate (Walker and Dagger 1993:17). A 1993 Australian Bureau of Statistics (ABS) victim survey found that $6.8 \%$ of households experienced at least one burglary or attempted burglary (1994:1). Walker and Dagger reported that about an equal number of attempted burglaries occurred in comparison to successful burglaries, and that around a quarter of victims were burgled more than once in a year (1993:16). Burglary figures are much larger when theft from a garage and theft from a car are counted as 'burglary' (3.8\% and 6.4\% respectively). The ABS reported that in 1996 across Australia there were 399,735 cases of 'unlawful entry with inten', up slightly from 384,897 in 1995 . About $80 \%$ of these cases are estimated to be related to property theft (ABS 1997:91, 1996:6). Australia's population increased slightly in this period. Burglary rates therefore provide a more accurate picture and show a stable pattern. Figure 3 shows that cases of 'break, enter and steal' reported to police increased fractionally from 2,041 per 100,000 persons in $1991 / 2$ to 2,053 in 1993/4 and then declined to 1,966 in 1995/6 (Mukherjee et al 1997:2). 
Figure 3 Reported rates of break, enter and steal, Australia, 1991/2-1995/6*

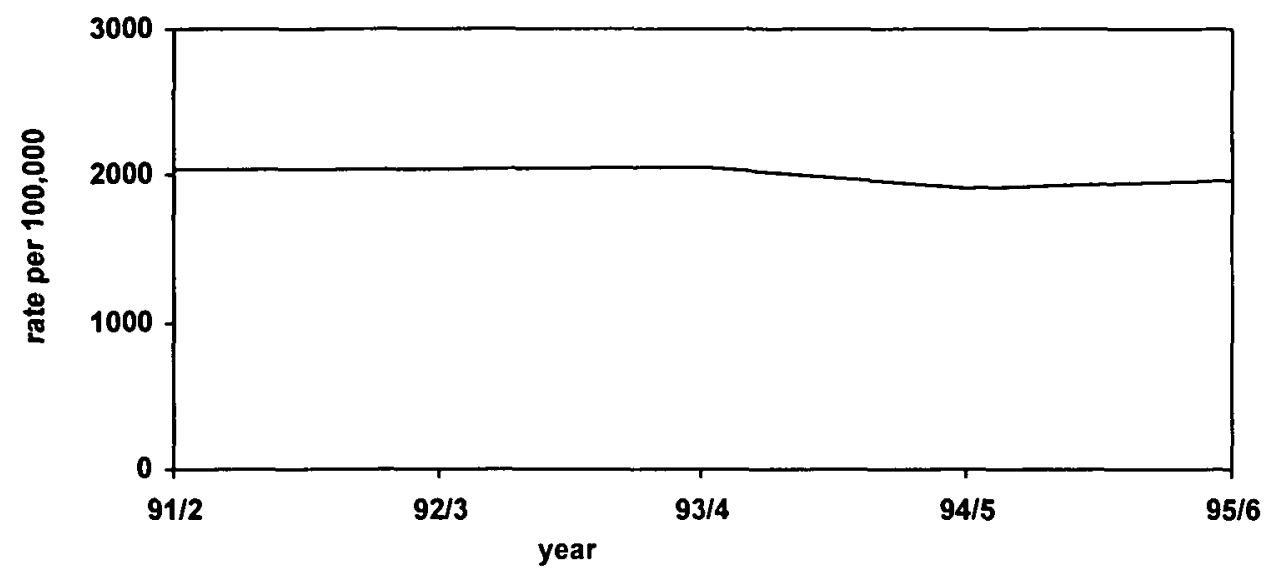

* Source: Mukherjee et al. 1997:2.

Figures vary between States. Western Australia has had the highest rate with 3,524 cases of unlawful entry with intent per 100,000 persons in 1995. The Northern Territory had the next highest rate $(3,039)$; with Victoria the lowest $(1,575)$ and the ACT the second lowest $(1,602)$ (ABS 1996a:6). Queensland had a fairly average rate. An ABS survey estimated on 1995 levels that Queensland households could expect to be burgled once every 16 years (ABS 1996b). Nonetheless, comparing States appears largely irrelevant because of their internal diversity. Regional comparisons show sharp differences in burglary patterns. For example, the NRMA reported that the Central West region of NSW experienced a $5 \%$ drop in claims in 1995/96 while, in Sydney, the local government area of Strathfield experienced an $86 \%$ increase (NRMA 1996).

In residential burglaries the most commonly stolen items are jewellery and cash, followed by videoplayers, hi-fis, tools, CDs and tapes, watches and TVs (Bridgeman and Taylor-Browne 1996; NRMA 1996). Burglary is also a major source of illegal firearms (Corkery 1994). One UK study found that only $7 \%$ of stolen property was recovered and half the victims were uninsured (Coupe and Griffiths 1996). On average, in recent years, residential burglaries in Australia resulted in the loss of about $\$ 2,000$ worth of property and damage of about $\$ 150$ (Walker and Dagger 1993:16). For 1996 the total cost of all commercial and non-commercial burglary offences in Australia reported and unreported has been estimated at $\$ 1,193$ million (Walker 1997:3).

Even where the monetary value of stolen goods is low, burglary often produces severe psychological effects for up to 12 months. Victims feel their personal space and sentimental valuables have been violated. Insomnia, depression and insecurity are typical symptoms (Nicolson 1994). Women report longer term anxiety (Coupe and Griffiths 1996). Burglary keeps home insurance costs high and, along with other 'street crimes', accelerates neighbourhood decay, retreat into private fortresses and recourse to private security services (Taylor 1995). Although traumatic, burglary needs to be considered in the context of all crime. For Australia, the financial cost has been estimated at approximately $6 \%$ of the estimated cost of crime compared, for example, to the estimated cost of fraud at between $15 \%$ 
and $18 \%$ (figures include criminal justice system costs) (Walker 1997:6). A recent study of Australian burglary rates and public perceptions showed that, on the whole, public fear of burglary is well out of proportion to risk (Weatherburn et al 1996).

The First National Survey of Crimes Against Businesses in Australia (Walker 1994) found that burglary of commercial premises was the most common crime, accounting for about $27 \%$ of businesses victimised. Commercial burglary cost about the same as residential burglary: approximately $\$ 435$ million in 1992 , which was about $8 \%$ of the total cost of crime to business. Small businesses were most vulnerable and only $63 \%$ of victims were fully insured (see also Grabosky 1995).

\section{Demographics of targets}

Residential burglary can occur across all socio-economic levels (Gillham 1991; Walker and Dagger 1993). Affluent homes often attract skilled professional burglars and residents living in poorer areas are vulnerable to the more typical offender who lives in close proximity (de Frances and Titus 1993). Although victimisation of burglary is experienced across the social spectrum, victimisation is correlated with certain demographics (Farrell 1992). More vulnerable households tend to be in lower socio-economic areas with generally high crime rates (Block 1993), and victimisation is higher in communities that lack social cohesiveness (Lynch and Cantor 1992). Victimisation rates in Australia are higher for householders in their accommodation for less than one year and victimisation tends to decrease with length of occupancy (ABS 1994).

Australian research supports overseas findings that the number of people in a household is a crucial element of risk. Households headed by married couples have less chance of being victimised than other types of families. Single parent families are a high risk group (Lindsay and McGillis 1986; ABS 1994; Phillips 1995; Mukherjee et al 1997), as are young urbanised professionals who reside in poorer areas (Trickett et al 1995). These people tend to be single renters and frequently leave their homes empty for long periods or go out frequently (Sampson and Wooldredge 1987; see also Walker and Dagger 1993; ABS 1994). Different housing types experience different victimisation risks. The 1989 international survey reported that detached houses are the most victimised in Australia, in contrast to the greater vulnerability of apartments in many other countries (van Dijk et al 1991; Trickett et al 1995). However, Walker and Dagger's (1993:46) survey found that flats and apartments in Australia experienced almost twice as many incidents as detached houses.

Time of day can also be an important variable. A US study (Cromwell et al 1991) suggested $75 \%$ of burglary offences are the result of opportunistic exploitation of temporary vulnerability. For example, the morning hours of a weekday are a common time for houses to be left empty; the occupants being either at work, taking children to school or shopping. During other periods of the day the property may be safe (see also Sparks 1981).

\section{Demographics of burglars}

Burglars appear to be much the same in all Western countries. About $80 \%$ are young males, aged $15-25$, with a record of school failure, family conflict, poor parental involvement in schooling, and substance abuse. As many as $80 \%$ of offenders may be unemployed (Smith et al 1992; Britt 1994; CJC 1996). Most are repeat offenders, unskilled and leisure oriented, with weak bonds to conventional society and little or no empathy for victims (Wright and Decker 1994; Salmelainen 1995). Disadvantaged ethnic minorities figure disproportionately in the profile. Although most burglars do not enjoy what they do, they often feel under 
intense pressure to obtain money quickly for drugs, alcohol and conspicuous consumption tied to peer group status (Wright and Decker 1994; Salmelainen 1995). Despite the implication from this profile of economic and cultural 'need' as a causal factor (Weatherburn 1992), it has been argued that 'a significant proportion' of burglars are casual opportunists, easily deterred by difficulty of access and the chance of being identified (Grabosky 1995:2; see also Findlay et al 1990:6). Few perpetrators are self-initiating but are introduced to burglary by peers (Biron and Ladouceur 1991; Wright and Decker 1994). One Australian study has shown that in some areas upwards of $20 \%$ of offenders may be responsible for $75 \%$ of offences (Salmelainen 1995:24).

Burglars prefer to do their work outside their immediate neighbourhood, and are relatively mobile in the search for targets by foot, motor vehicle or public transport. Nonetheless they tend to live in the same band of suburbs where most burglaries are committed: areas with large populations of young people and high levels of family disorganisation (Patterson 1991). The large majority prefer empty premises and avoid contact with victims (Grabosky 1995). Most grow out of it, but a small core will move on from simple burglary to aggravated burglary, armed robbery and other major crimes.

Age, gender and class are the most significant variables in the profile of burglars (when location and unemployment are seen as effects of class). Self-report studies suggest that the female burglary rate is higher than official statistics show, and some adjustment of the standard 5/1 ratio may be needed (Ogilvie 1996). However, a recent Australian survey of young people found that, of those admitting to attempted burglary, $78.6 \%$ were male and $21.4 \%$ were female (Ogilvie 1996). Additionally, females appear to begin burglary at a later age, and tend to act as accessories to males (Decker et al 1993). Lower class females (including those in the so-called 'underclass' or 'surplus class') are much more likely to be involved in burglary than young women generally (Simpson and Ellis 1994).

\section{Theorising causality}

The above analysis invites a theoretical explanation which is necessarily integrated. Most of the major criminological theories can be seen to provide partial explanations: strain, social bonding, social disorganisation, social learning, feminist and opportunity theories. In countries like Australia, the causal factors are so intermeshed and resistant to precise quantification that any percentage attribution of responsibility can only be extremely tentative, and would vary significantly between locations (Weatherburn 1992). Opportunity clearly has little importance unless motives are present; and powerful motives can be de-activated by lack of opportunity. As one study of offender decision making concluded:

Though our burglars made conscious choices throughout their crimes [as suggested by the rational choice model of decision making] their offending did not appear to be an independent, freely chosen event so much as it was part of a general flow of action emanating from and shaped by their involvement with street culture (Wright and Decker 1994:205).

Feminist theoretical approaches are particularly applicable where they attempt to explain the extreme disproportions in offending between males and females. Burglary would seem to be closely related to male socialisation into more risk-taking, less empathetic, traits; and related to conflict between masculine status and the failure of many young men in education and the labour force. Anti-social behaviour is one side of the risk-taking coin. The other side, which should perhaps be of greater concern than burglary, is self-destruction manifested in higher rates of suicide, drug-taking, accidents and preventable diseases (Indermaur 1995). Many so called 'career' burglars and thieves are particularly vulnerable to over-confidence, poor risk calculations, and lack of sophistication or control in most aspects of their lives. 
Many have developed intense resentments and seek indiscriminate revenge based in part on genuine injustices experienced in institutions, including criminal justice institutions (Shover 1996).

The question of masculinity in crime causation is one that cannot be conveniently applied to a criminal underclass by middle and upper class males. White collar crime is also symptomatic of the problem, and 'street crimes', such as burglary, are not exclusive to the lower classes. Middle class fathers may generate relatively more law-abiding, less physically aggressive, sons. But these fathers' physical and mental absence from parenting is nonetheless destructive, with its own form of anti-social role modelling (Collier 1995). Middle and upper class 'success' is also a product of 'competing masculinities' and a 'hierarchy of masculinities' (Collier 1995:211, 210) which has lower class male burglary rates as one of the outcomes as the losers in the competition seek to play by other rules.

Theories of psychological and biological abnormality appear to have little relevance to burglary as broad explanations. Similarly, a simplistic classical theory of the fully responsible 'rational economic man' is also of extremely limited utility in understanding or preventing burglary. Nonetheless, it is this latter view which has driven masculinised government control efforts.

\section{What doesn't work}

The traditional criminal justice system approach to burglary prevention has involved two elements: police emergency response intervention; and investigation, prosecution and punishment. These are based on principles of general deterrence (scaring off potential offenders) and specific deterrence (scaring off potential re-offenders), but also extend to the incapacitative effect of incarceration. This is a failed model.

Numerous reviews identify a high rate of reportage of burglary. Van Dijk, Mayhew and Killias cited a figure of $81 \%$ for their international study (1991:25) and Walker and Dagger (1993:17) cited 89\% for Australia, although Felson (1994:8) reported a much lower rate of $39 \%$ based on a US National Crime Survey. Whatever the case with reportage, burglary has an extremely low conviction rate. Typically less than $10 \%$ of offences result in convictions. Some surveys report conviction rates of less that $2 \%$ (Felson 1994:9). New South Wales police clear about $5 \%$ of cases each year; about $67 \%$ of arrestees are convicted and only $27 \%$ of these are jailed (in Weatherburn and Grabosky 1997:7). Each year in Australia a small ramshackle 'army' of about 30,000 young men engage in burglary. Their guerilla-like tactics in the urban maze make them virtually untouchable (Weatherburn and Grabosky 1997:10).

Contrary to incapacitation theory, liberal probation and parole policies do not appear to increase burglary rates (Neithercutt et al 1990; Geerken and Hayes 1993). Even if numerous burglaries are committed by offenders on bail (Avon and Somerset Constabulary 1991; Morgan 1992), eliminating bail is not necessarily a solution. One study found that burglars who spent time in jail quickly made up for lost time, so their rates of burglary over time equalled those of their un-incarcerated colleagues (Hurrell 1993). Some studies indicate that imprisonment is in fact positively correlated with burglary (Gray 1994), which of course makes sense from a social learning perspective. (For a current extensive review of sentencing for deterrence and incapacitation, see Mackenzie 1997, also Shover 1996.)

Other studies suggest a slight decrease in burglary as a result of increased enforcement (for example, Clarke 1994). Improvements in police responses may produce minor reductions but the effect is very dependent on jurisdictional demographics and is difficult to sustain (Chamlin 1991). Technological improvements, in fingerprinting for example, may 
increase convictions (KCJSAC 1990), but this will not necessarily flow on to substantial reductions in offences and the costs may outweigh the benefits. A study of the impact of the UK Police and Criminal Evidence Act (PACE) on burglary showed that changes to police powers and procedures - such as detaining suspects for questioning - produced greater 'professionalism' in handling cases but no consistent improvement in conviction rates across jurisdictions and no demonstrable reduction in offences (Brown 1991). The Queensland Police Service has estimated that the annual cost of responding to reported residential burglaries is approximately $\$ 6.5$ million (CJC 1996:2). The Service recently caused controversy on the Gold Coast when it elected not to respond to reports of burglaries with less than $\$ 1,000$ worth of losses.

Burglars are afraid of being caught (Decker et al 1993), but they perceive their chances of being caught as extremely low. Burglars who are caught do not expect to be caught and do not expect to be caught again. On the whole, this is an objective perspective, given the extremely low conviction rates. One study found that only $1 \%$ of burglaries involve the perpetrator being caught in the act (Felson 1994:11). This is predictable in the context of police patrol capacity. An analysis in Los Angeles County estimated that full deployment of patrol officers would provide each premises with half a minute of protection in every 24 hour period. Doubling the number of police would provide one minute of protection (Felson 1994:11).

Given the limits on the criminal justice system, a French study concluded that 'the insurance market and the security industry manage the problem of theft and burglary: the market takes over where the state fail' (Zauberman and Robert 1990:1). Prospective targets of burglary can take steps to improve their security in ways that reduce their likelihood of victimisation or provide some redress through insurance. But one strategy that does not work is physical resistance including resort to firearms. Despite some recent cases in Australia where burglars have been shot and the attempted burglaries have been prevented, resistance is likely to cause physical damage to the victim (Indermaur 1995:16-17).

Contrary to what many right-wing politicians believe - including the right-wing of the Australian Labor Party - the public do not have a strongly punitive view of burglars. Opinion surveys vary in their findings, but even where a punitive view is taken, it is accompanied by support for rehabilitation, especially where the offender is socially disadvantaged (McCorkle 1993). Most victims appear to prefer compensation, rehabilitation, remorse and reconciliation over punishment (Umbreit 1990). Community service orders are a favoured option over imprisonment or fines (van Dijk et al 1991; Walker and Dagger 1993:101). There may be an implicit recognition in these views of the practical limitations of punishment and the place of disadvantage in offender motivations.

\section{What seems to work}

The above analysis suggests that the best way to prevent burglary is to stay at home - or at least to live in a large household where there is likely to be someone home most of the time. However, such arrangements do not suit many people.

Burglary prevention can be separated into two main approaches: situational interventions and social interventions. The former focuses on reducing opportunities in the immediate context of the crime event, while the latter focuses on changing dispositional factors. Overlaps are of course possible between the two approaches. 


\section{Situational prevention}

Protective measures such as target hardening are the most popular means adopted by property owners to deter burglars and are being promoted in the Australian National Campaign Against Violence and Crime. There is some evidence from Australian research that dogs are a good deterrent, although they require a lot of attention. Surprisingly perhaps, there is little evidence in the Australian context of a definite significant preventive effect from special locks, grills, high fences or alarms (Walker and Dagger 1993:30). Walker (1994:83) and van Dijk et al (1991:88) found that premises with alarms were more likely to be burgled. However, this could be because more vulnerable homes and businesses may be more likely to install alarms. Van Dijk et al, in their international study, noted that alarm owners appear to have higher rates of attempted burglary. The insurance industry gives cautious support to the use of alarms and other security devices, although it recognises there is a major problem with the 'human factor'. The NRMA reported that in $49 \%$ of cases where homes with alarms had been burgled, the alarm was not on at the time (NRMA 1996:8). However, two American studies have found that homes with alarms and other forms of security are much less likely to be burgled (Buck et al 1993). One of the studies found the combined presence of a 'primary guardian' (a householder) and 'proxy guardians' (security devices) greatly reduced the risk of burglary (Garofalo and Clark 1992). Dogs appeared to be of no benefit in these studies.

One of the most famous anti-burglary initiatives, the Kirkholt Project in the UK, used free security hardware upgrades on a housing estate to prevent repeat victimisation. The project included other elements such as removal of coin operated fuel meters and a specific form of Neighbourhood Watch (described below). An important observation of the project team was that the effectiveness of security hardware is dependent on various contextual factors. For example, neighbours need to be in close proximity to respond to noise from attempted entry, and security levels need to be consistent. Good window locks are of little use if door locks are weak (Forrester et al 1988). Similarly, the Shield of Confidence security program, developed in Hamilton-Wentworth Ontario in the $1980 \mathrm{~s}$, involved police certification of a basic standard of home security involving quality of locks, doors and windows, security on garages and exterior lighting. Certified homes received an insurance discount. In two reviews of incidents, there were only three cases of certified homes being burgled and these resulted from failure to activate locks. The same area was subject to an annual burglary rate of one in 16 homes (in Sarkissian 1992). It is notable that in 1996 the NRMA withdrew its sponsorship of Neighbourhood Watch and put funds instead into a discount scheme for clients with alarms (as well as some funding of social prevention initiatives including an after school recreational program and an after-school tuition program) (NRMA 1996:28-29).

Appropriate security management in commercial premises can reduce vulnerability where a comprehensive security plan is adopted, regular risk analyses are conducted, and personnel security is integrated with physical security. However, in many commercial and public sector agencies, security management is marginalised and subject to counter-productive under-funding (Fischer and Green 1992).

Burglars frequently do not obtain sufficient cash for their needs and are obliged to sell stolen property. Targeting receivers is one way of trying to reduce this market, and is another strategy proposed in the National Campaign. Reducing demand can be pursued through police stings in setting up dummy secondhand dealers, or through tighter controls on dealers such as requiring proof of identity from suppliers and recording item numbers. These approaches 'make sense', but are still largely in an experimental phase. They require 
computerisation and determined regulatory intervention into the secondhand goods sector (Jochelson 1995; NRMA 1996). Enforcement of such regulations provides a potentially more productive role for police in burglary reduction than pursuing offenders (Weatherburn and Grabosky 1997).

Property marking is a strategy closely related to targeting receivers. An intensive property marking scheme amongst relatively isolated villages in the UK in South Wales showed significant success (Laycock 1992). The scheme involved a $72 \%$ participation rate and depended on widespread publicity which got the message home to both 'law abiding' residents and resident burglars. The first year of operation saw a $40 \%$ drop in offences. In a two year period participants experienced a $60 \%$ drop in offences, with no evidence of displacement.

Neighbourhood Watch has received a great deal of support in Australia but it has produced mixed results (Bayley 1989). It can be beneficial but tends to be more successful in higher income areas in which there are adequate numbers of residents at home for sufficient lengths of time to make surveillance work. In the UK, a more refined version of Neighbourhood Watch - Cocoon Watch - has shown promise. Cocoon Watch was developed as part of the Kirkholt Project and was based on the probability of repeat victimisation. Within 24 hours of an incident, a Crime Prevention Officer counselled the resident and conducted a security audit on the premises. In the Kirkholt Project, upgrading was paid for as a part of the project. Additionally, with Cocoon Watch, victims' immediate neighbours were asked to make an extra effort to be aware of strangers in the area. Participating neighbours were also given free security upgrades. This process was repeated for every victimised person during the running of the project. By targeting only repeat victimisation, a burglary reduction of $75 \%$ was claimed with no observable displacement (Forrester et al 1988). However, the first Australian study of repeat burglary victimisation (Guidi et al 1997) indicated that the greater spread of repeat burglaries in Australian suburbia is less conducive to this type of intervention. Partial replications of the Kirkholt Project have not been as successful, but neither have they matched the conditions present in Kirkholt, which was a small, clearly bounded, estate with limited access, high cultural homogeneity and high burglary rates. Replications have also been less scientifically grounded, and not resourced or organised to the same degree (Tilley 1993).

Some other 'situational' measures show promise for burglary prevention. The lower rate of burglary amongst home owners suggests that greater home ownership could facilitate less crime. Home owners are more likely than tenants to stay at home; and home ownership is associated with greater neighbourhood stability, sense of community and defensibility, and participation in Neighbourhood Watch (Sampson 1985; Sampson and Wooldredge 1987; Maltz et al 1990; Hope 1995). In group housing such as unit complexes, there is also some potential for 'concierges' and caretakers to contribute to the prevention of crime and disorder, including burglary prevention (van Dijk et al 1991; Hesseling 1992; Safe Neighbourhoods Unit 1993).

The measures described above have been criticised on several grounds. They are seen as contributing to a 'fortress society', as exacerbating fear of crime, and driving people indoors behind shuttered windows. The costs involved also mean that target hardening is more accessible to those who have the capacity to pay. 'Cocoon Watch', caretakers and surveillance cameras are seen as robbing people of privacy, and feared as part of an over-regulated society (see O'Malley 1994; also Clarke 1992:27-36). These arguments are difficult to dispute in principle and certainly point to some probable unintended consequences of preventive efforts. However, various forms of opportunity reduction will be the necessary immediate 
resort of those who are vulnerable, and critiques of privatised crime prevention must be wary of underestimating the impacts and fear of victimisation. It must also be appreciated that reducing offending through opportunity reduction will also reduce the consequential costs and stigmatising effects of punishment on young offenders. This is especially the case where burglary tends to be opportunistic or where there is little possibility of displacement.

\section{Social prevention}

Recent reviews of burglary in Australia have tended to focus on situational prevention at the expense of social measures (Grabosky 1995; CJC 1996) - a tendency to some extent reflected in the allocation of funds in the National Campaign Against Violence and Crime. A major problem with social prevention programs is lack of rigorous evaluation. One review of 120 programs in the US found that only $4 \%$ had utilised any form of pre- and posttest data (in Witt and Crompton 1996:28). A difficulty for evaluation is that programs are usually aimed at generalised effects. Impacts specific to burglary are difficult to precisely distinguish. But despite the methodological problems, recent international reviews of a diverse range of 'social' or 'community-based' prevention programs have challenged the 'nothing works' thesis popularised in the 1970s. Careful attention to participant selection, program design, personnel, and evaluation can produce reductions in offending and reoffending - in large part by meeting physical and emotional needs (providing a stake in conformity), and occupying time (for example, Findlay et al 1990; Hollin 1990; Grabosky and James 1995; Farrington 1996; Witt and Crompton 1996).

The majority of these programs are aimed at adolescents in the 'at-risk' category. For example, Findlay et al (1990) described 12 programs in the UK categorised as 'neighbourhood-based youth initiatives', 'issue-based youth initiatives' and 'police and school initiatives'. Some projects claimed reduced burglary levels in local areas of between $36 \%$ and $44 \%$. Also in the UK, a Young Offender Community Support Scheme involved placing young offenders - most of whom had been convicted for burglary - into custodial caregiver families. A non-re-offending rate of approximately $80 \%$ was claimed over eight months compared to a similar re-offending rate for the control group (Field 1992).

For younger burglars, marijuana, alcohol and stimulants are sources of the demand for cash and the reduction of inhibitions. Money for heroin is a significant motive for older burglars. An experiment in Merseyside beginning in the late-1980s involved the provision of methadone on a large scale, using a multi-agency approach, with highly qualified committed staff, and with strong police support (provided at the 'expense' of foregone arrests). Interviews with participants indicated a $50 \%$ reduction in the number engaged in acquisitive crimes, contributing to a substantial reduction in burglaries at a time of rapidly increasing crime in nearby areas (Parker and Kirby 1996; see also Hall 1996, and Bell 1997 for an Australian study).

Social prevention programs suffer from under-funding, instability in funding, lack of staff training, and lack of long term follow-up including employment placement and provision of accommodation (Barker et al 1992; Field 1992). They tend to be highly dependent on the skills and personalities of program operators, and face considerable difficulties in sustaining reform after 'graduation' (Hollin 1990). Many have been criticised for poor ethical standards related to addressing the full range of participants' problems, as well as inadequate consultation with participants, and lack of equal opportunities (Findlay et al 1990). However, the limited successes of such programs should not be seen as inherent limitations, but as indicators of their potential and the need for much greater government support. 
Crime prevention programs aimed at young people can fail to show substantial reductions in offending for a wide variety of reasons. One factor is the relative lateness of the intervention at the time of onset of symptoms. Early childhood interventions - also being considered as part of the National Campaign Against Violence and Crime - attempt to go back to the starting point of social development. Tremblay and Craig (1995) reviewed programs focused on strengthening families with young children, and improving preschool and elementary school participation. These programs, such as the famous High/Scope Perry Preschool Project, involved a variety of strategies including nutritional advice and parent training, social skills training, conflict resolution, and extra-curricula teaching support. Tremblay and Craig concluded their review of developmental interventions on a positive note:

A large number of perinatal and preschool studies have shown that interventions with highrisk families can change the parenting behaviour many theories identify as the first part of a chain of events that leads to antisocial behaviour ... money invested in early (e.g., preschool) prevention efforts with at-risk families will give greater payoffs than money invested in later (e.g., adolescence) prevention efforts with the same at-risk families (1995:218, 224; see also Sherman 1997).

From a feminist perspective, developmental interventions would focus on 'feminising' boys into the same pro-social traits acquired by women (Heidensohn 1985). For example, in Boys Will Be Boys: Breaking the Link Between Masculinity and Violence, Myriam Miedzian (1991) described programs that included girls but concentrated on reducing antisocial behaviour by boys. One program involved long-term training of children in infant care, thereby developing nurturing capabilities and empathy. The report did not include rigorous evaluation of outcomes but the program is rich in potential for contributing to reductions in various crimes including burglary.

\section{Conclusions}

The causes of burglary and solutions to the problem are complex. Improved guardianship using a range of measures to deter offenders can be of some benefit. However, the size of the burglary opportunity structure in Australia suggests that the $\$ 330,000$ allocated by the National Campaign Against Violence and Crime in this category will quickly dissipate, even with the addition of funds from jurisdictions where pilot projects are located. Furthermore, close attention will need to be given to economic and social disadvantage to ensure equity in the determination of project locations.

The existing literature suggests, however, that developmental interventions hold substantial promise for crime prevention with the additional advantage of the more obvious incorporation of social justice. From a social contract perspective, the right to punish claimed by civil society needs to be balanced by a duty to assist young people. Mainstream society should first provide flexible schooling, full employment, housing and protection from abuse before apportioning moral blame and prescribing large doses of punishment (see Shover 1996:185-186). The relatively small allocation of funds to social prevention in the National Campaign is disappointing and augers badly for the success of the whole campaign. Perhaps the policy priorities reflect the fact that situational interventions appear to provide quicker returns, including a more immediate political pay-off. Social intervention, on the other hand, is a long term strategy with results well beyond the time of 'the next election'. Perhaps even more telling is the point that developing social interventions which take account of the masculinised nature of crime must also take account of the masculinised nature of government decision making: "How do you put "changing men" on the political agenda?' (Collier 1995:212). 
In burglary, as with many crimes, there can be little doubt that most 'offenders' are also 'victims' - of the failure of families and the failure of society to meet the needs of young people. The focus in burglary prevention must be on the problem of seriously alienated young men and the intense role conflicts they experience in the transition from childhood to adulthood in an intensely competitive society. An enormous investment is urgently needed to integrate this group into a more caring society. The situation has been summarised perfectly by David Indermaur in his book Violent Property Crime:

Crime is only one symptom - along with substance abuse and suicide - of the crisis of young males in today's society. In addition to reducing opportunities for crime, crime prevention must recognise that the propensity to offend is a function of the psychological and social pressures experienced by the core offending group: young men (1995:indexed abstract).

\section{REFERENCES}

ABS (1994) April 1993 Crime and Safety Australia, Australian Bureau of Statistics, Canberra.

ABS (1996a) 1995 National Crime Statistics, Australian Bureau of Statistics, Canberra.

ABS (1996b) Crime and Safety, Queensland, Australian Bureau of Statistics, Canberra.

ABS (1997) 1996 Recorded Crime Australia, Australian Bureau of Statistics, Canberra.

Avon \& Somerset Constabulary (1991) The Effect of Re-offending on Bail on Crime in Avon and Somerset, Bristol, UK.

Barker, M, Pease, K \& Webb, B (1992) Community Service and Crime Prevention: The Cheadle Heath Project, Police Research Group, Home Office, London.

Bayley, D (1989) 'Community Policing in Australia: An Appraisal' in Chappell, D \& Wilson, P (eds) Australian Policing: Contemporary Issues, Butterworths, Sydney.

Bell, J (1997) 'Methadone and Property Crime', paper presented at the Second National Outlook Symposium, Australian Institute of Criminology, Canberra, 3-4 March.

Biron, L \& Ladouceur, C (1991) 'The Boy Next Door: Local Teenage Burglars in Montreal', Security Journal, vol 2, no 4, pp 200-204.

Block, C (1993) 'STAC Hot Spot Areas: A Statistical Tool for Law Enforcement Decisions' in Proceedings of the International Seminar on Environmental Criminology and Crime Analysis, Florida Criminal Justice Executive Institute, Coral Gables, FL.

Bridgeman, C \& Taylor-Browne, J (1996) The PRG Burglary Manual, Police Research Group, Home Office, London.

Britt, C (1994) 'Crime and Unemployment Amongst Youths in the United States, 19581990', American Journal of Economics and Sociology, vol 53, no 1, pp 99-110.

Brown, D (1991) Investigating Burglary: The Effects of PACE, Home Office Research Study, HMSO, London. 
Buck, A, Hakim, S \& Rengert, G (1993) 'Burglar Alarms and the Choice Behavior of Burglars: A Suburban Phenomenon', Journal of Criminal Justice, vol 21, no 5, pp 497-507.

Chamlin, M (1991) 'A Longitudinal Analysis of the Arrest-Crime Relationship', Justice Quarterly, vol 8, no 2, pp 187-200.

CJC (1996) Residential Burglary in Queensland, Criminal Justice Commission, Brisbane.

Clarke, R (1992) Situational Crime Prevention: Successful Case Studies, Harrow and Heston, New York.

Clarke, S (1994) 'Some Basic Concepts of Penal Sanctions', Popular Government, summer, pp 16-24.

Cohen, L \& Felson, M (1979) 'Social Change and Crime Rate Trends: A Routine Activity Approach', American Sociological Review, vol 44, August, pp 588-608.

Collier, R (1995) “"A Father's 'Normal' Love"?: Masculinities, Criminology and the Family' in Dobash, R, Dobash, R \& Noaks, L (eds) Gender and Crime, University of Wales Press, Cardiff.

Corkery, J (1994) Theft of Firearms, Home Office, Research and Planning Unit, London.

Coupe, T \& Griffiths, M (1996) Solving Residential Burglary, Police Research Group, Home Office, London.

Cromwell, P, Olson, J \& Avary, D (1991) Breaking and Entering: An Ethnographic Analysis of Burglary, Sage, Los Angeles.

Decker, S, Wright, R \& Logie, R (1993) 'Perceptual Deterrence Among Active Residential Burglars', Criminology, vol 31, no 1, pp 135-147.

Decker, S, Wright, R \& Redfern, A (1993) 'A Woman's Place is in the Home: Females and Residential Burglary', Justice Quarterly, vol 10, no 1, pp 143-162.

de Frances, C \& Titus, R (1993) 'The Environment and Residential Burglary Outcomes' in Proceedings of the International Seminar on Environmental Criminology and Crime Analysis, Florida Criminal Justice Executive Institute, Coral Gables, FL.

Farrell, G (1992) 'Multiple Victimisation: Its Extent and Significance', International Review of Victimology, vol 2, pp 85-102.

Farrington, D (1996) Understanding and Preventing Youth Crime, Joseph Rowntree Foundation, UK.

Felson, M (1994) Crime and Everyday Life, Pine Forge Press, Thousand Oaks, CA.

Field, S (1992) 'Young Offenders Community Support Scheme - Hampshire, England', Community Alternatives, vol 4, no 2, pp 77-96.

Findlay, J, Bright, J \& Gill, K (1990) Youth Crime Prevention: A.Handbook of Good Practice, Crime Concern, Swindon, UK.

Fischer, R \& Green, G (1992) Introduction to Security, Butterworth-Heinemann, Boston. 
Forrester, D, Chatterton, M \& Pease, K (1988) The Kirkholt Burglary Prevention Project, Rochdale, Crime Prevention Unit, Home Office, London.

Garofalo, J \& Clark, D (1992) 'Guardianship and Burglary', Justice Quarterly, vol 9, no 3, $443-463$.

Geerken, M \& Hayes, H (1993) 'Probation and Parole: Public Risk and the Future of Incarceration Alternatives', Criminology, vol 31, no 4, pp 549-564.

Gillham, J (1991) Preventing Residential Burglary: Towards More Effective Community Programs, Springer-Verlag, New York.

Grabosky, P (1995) 'Burglary Prevention', Trends and Issues in Crime and Criminal Justice, no 49, Australian Institute of Criminology, Canberra.

Grabosky, P \& James, M (1995) The Promise of Crime Prevention: Leading Crime Prevention Programs, Australian Institute of Criminology, Canberra.

Gray, T (1994) 'Using Cost-Benefit Analysis to Measure Rehabilitation and Special Deterrence', Journal of Criminal Justice, vol 22, no 6, pp 569-575.

Guidi, S, Townsley, M \& Homel, R (1997) 'Repeat Break and Enter Crimes: An Analysis of Police Calls for Service Data in a Brisbane Region', paper presented at the Second National Outlook Symposium, Australian Institute of Criminology, Canberra, 3-4 March.

Hall, W (1996) 'Methadone Maintenance Treatment as a Crime Control Measure', Crime and Justice Bulletin, no 28, NSW Bureau of Crime Statistics and Research, Sydney.

Heidensohn, F (1985) Women and Crime, Macmillan, London.

Hesseling, R (1992) 'Social Caretakers and Preventing Crime on Public Housing Estates' in Dutch Penal Law and Policy 06, 05-1992, Ministry of Justice, Research and Documentation Centre, The Hague.

Hollin, C (1990) Cognitive-Behavioral Interventions with Young Offenders, Pergamon, New York.

Hope, T (1995) 'The Flux of Victimisation', British Journal of Criminology, vol 35, no 3, pp 327-342.

Hurrell, K (1993) 'Modelling the Relationship Between Crime Count and Observation Period in Prison Inmates' Self-Report Data', Applied Statistics, vol 42, no 2, pp 355-367.

Indermaur, D (1995) Violent Property Crime, Federation Press, Sydney.

Jochelson, R (1995) 'Household Break-Ins and the Market for Stolen Goods', Crime and Justice Bulletin, no 24, NSW Bureau of Crime Statistics and Research, Sydney.

KCJSAC (1990) Estimating the Impact of Automated Fingerprint Identification in Kentucky, Kentucky Criminal Justice Statistical Analysis Centre, Frankfort, KY.

Laycock, G (1992) 'Operation Identification, Or the Power of Publicity?' in Clarke, R (ed) Situational Crime Prevention: Successful Case Studies, Harrow and Heston, New York. 
Lindsay, B \& McGillis, D (1986) 'Citywide Community Crime Prevention: An Assessment of the Seattle Program' in Rosenbaum, D (ed) Community Crime Prevention: Does it Work?, Sage, Los Angeles.

Lynch, J \& Cantor, D (1992) 'Ecological and Behavioural Influences on Property Victimisation at Home: Implications for Opportunity Theory', Journal of Research in Crime and Delinquency, vol 29, no 3, pp 335-362.

MacKenzie, D (1997) 'Criminal Justice and Crime Prevention' in Sherman, L, Gottfredson, D, MacKenzie, D, Eck, J, Reuter, P \& Bushway, S (eds) Preventing Crime: What Works, What Doesn't, What's Promising, National Institute of Justice, Washington, DC, http:// www.ncjrs.org/works/index.htm.

Maltz, M, Gordon, A \& Friedman, W (1990) Mapping Crime in its Community Setting: Event Geography Analysis, Springer-Verlag, New York.

McCorkle, R (1993) 'Punish and Rehabilitate? Public Attitudes Towards Six Common Crimes', Crime and Delinquency, vol 39, no 2, pp 240-252.

Miedzian, M (1991) Boys Will Be Boys: Breaking the Link Between Masculinity and Violence, Doubleday, New York.

Morgan, P (1992) Offending While on Bail, Research and Planning Unit, Home Office, London.

Mukherjee, S, Carcach, C \& Higgins, H (1997) A Statistical Profile of Crime in Australia, Australian Institute of Criminology, Canberra.

NCAVC (1997) Project Summaries, National Campaign Against Violence and Crime, Canberra.

Neithercutt, M, Carmichael, B \& Mullen, K (1990) 'A Perspective on Determinate Sentencing', Criminal Justice Policy Review, vol 4, no 3, pp 201-213.

Nicolson, P (1994) The Experience of Being Burgled, Sheffield University, Sheffield, UK.

NRMA (1996) Household Burglary in Eastern Australia 1995-1996, NRMA Insurance, Sydney.

Ogilvie, E (1996) 'Masculine Obsessions: An Examination of Criminology, Criminality and Gender', Australian and New Zealand Journal of Criminology, vol 29, no 3, pp 205-226.

O'Malley, P (1994) 'Neo-Liberal Crime Control - Political Agendas and the Future of Crime Prevention in Australia' in Chappell, D \& Wilson, P (eds) The Australian Criminal Justice System: The Mid 1990s, Butterworths, Sydney.

Parker, H \& Kirby, P (1996) Methadone Maintenance and Crime Reduction on Merseyside, Police Research Group, Home Office, London.

Patterson, E (1991) 'Poverty, Income Inequality, and Community Crime Rates', Criminology, vol 29, no 4, pp 755-776. 
Phillips, T (1995) 'State Differences in Burglary Victimisation in Australia: An Exploratory Analysis' in Crime Victims Surveys in Australia: Conference Proceedings, Criminal Justice Commission, Brisbane.

Safe Neighbourhoods Unit (1993) Housing and Safe Communities: An Evaluation of Recent Initiatives, Safe Neighbourhoods Unit, London.

Salmelainen, P (1995) The Correlates of Offending Frequency: A Study of Juvenile Theft Offenders in Detention, no 6, NSW Bureau of Crime Statistics and Research, Sydney.

Sampson, R (1985) 'Neighbourhood and Crime: The Structural Determinants of Personal Victimisation', Journal of Research in Crime and Delinquency, vol 22, no 1, pp 7-40.

Sampson, R \& Wooldredge, J (1987) 'Linking the Micro- and Macro-Level Dimensions of Lifestyle-Routine Activity and Opportunity Models of Predatory Victimisation', Journal of Quantitative Criminology, vol 3, no 4, pp 371-393.

Sarkissian, W (1992) 'Housing as if Safety Mattered: Environmental Crime Prevention Guidelines and Ideas from a Practitioner's Perspective' in Sarkissian, W (ed) Safe as Houses: Proceeding of the First Griffith University Workshop on Crime Prevention Through Environmental Design, Centre for Crime Policy and Public Safety, Griffith University, Brisbane.

Sherman, L (1997) 'Family-Based Crime Prevention' in Sherman, L, Gottfredson, D, MacKenzie, D, Eck, J, Reuter, P \& Bushway, S (eds) Preventing Crime: What Works, What Doesn't, What's Promising, National Institute of Justice, Washington, DC, http:// www.ncjrs.org/works/index.htm.

Shover, N (1991) 'Burglary' in Tonry, M (ed) Crime and Justice: A Review of Research, Chicago University Press, Chicago, IL.

Shover, N (1996) Great Pretenders: Pursuits and Careers of Persistent Thieves, Westview, Boulder, CO.

Simpson, S \& Elis, L (1994) 'Is Gender Subordinate to Class? An Empirical Assessment of Calvin and Pauly's Structural Marxist Theory of Delinquency', Journal of Criminal Law and Criminology, vol 82, no 2, pp 453-480.

Smith, M, Devine, J \& Sheley, J (1992) 'Crime and Unemployment: Effects Across Age and Race Categories', Sociological Perspectives, vol 35, no 4, pp 551-571.

Sparks, R (1981) 'Multiple Victimisation: Evidence, Theory and Future Research', Journal of Criminal Law and Criminology, vol 72, no 2, pp 763-778.

Taylor, I (1995) 'Private Homes and Public Others', British Journal of Criminology, vol 35, no 2, pp 263-285.

Tilley, N (1993) After Kirkholt - Theory, Method and Results of Replication Evaluations, Crime Prevention Unit, Home Office, London.

Tremblay, R \& Craig, W (1995) 'Developmental Crime Prevention' in Tonry, M \& Farrington, D (eds) Building a Safer Society: Strategic Approaches to Crime Prevention, University of Chicago Press, Chicago. 
Trickett, A, Osborn, D \& Ellingworth, D, (1995) 'Property Crime Victimisation: The Roles of Individual and Area Influences', International Review of Victimology, vol 3, no 4, pp 273-295.

Umbreit, M (1990) 'The Meaning of Unfairness to Burglary Victims' in Galaway, B \& Hudson, J (eds) Criminal Justice, Restitution, and Reconciliation, Criminal Justice Press, Monsey, NY.

van Dijk, J, Mayhew, P \& Killias, M (1991) Experiences of Crime Across the World: Key Findings of the 1989 International Crime Survey, Kluver, Boston, MA.

Walker, J (1994) The First Australian National Survey of Crimes Against Business, Australian Institute of Criminology, Canberra.

Walker, J (1997) 'Estimates of the Costs of Crime in Australia in 1996', Trends and Issues in Crime and Criminal Justice, no 72, Australian Institute of Criminology, Canberra.

Walker, J \& Dagger, D (1993) Crime in Australia, Australian Institute of Criminology, Canberra.

Weatherbum, D (1992) 'Economic Adversity and Crime', Trends and Issues in Crime and Criminal Justice, no 40, Australian Institute of Criminology, Canberra.

Weatherburn, D \& Grabosky, P (1997) 'Strategic Approaches to Property Crime Control', paper presented at the Second National Outlook Symposium, Australian Institute of Criminology, Canberra, 3-4 March.

Weatherburn, D, Matka, E \& Lind, B (1996) 'Crime Perception and Reality', Crime and Justice Bulletin, no 28, NSW Bureau of Crime Statistics and Research, Sydney.

Witt, P \& Crompton, J (1996) Recreation Programs that Work for At-Risk Youth, Venture, Pennsylvania.

Wright, R \& Decker, S (1994) Burglars on the Job: Street Life and Residential Break-Ins, Northeastern University Press, Boston, MA.

Zauberman, R \& Robert, P (1990) 'Victims as Actors of Social Control', International Review of Victimology, vol 1, no 2, pp 133-152. 